\author{
EWA PRZESZŁO \\ ORCID: 0000-0002-9649-4134 \\ Uniwersytet Śląski w Katowicach \\ ewa.przeszlo@us.edu.pl
}

\title{
Rola organizacji przedsiębiorców w sferze zamówień publicznych
}

\begin{abstract}
Abstrakt: W zamówieniach publicznych uczestniczyć mogą także organizacje zrzeszające przedsiębiorców. Takie organizacje funkcjonujące w Polsce mają zróżnicowany charakter prawny. Są to w szczególności organizacje samorządu zawodowego, izby gospodarcze oraz inne zrzeszenia. Z ustawy Prawo zamówień publicznych wynika ich uprawnienie do wnoszenia środków ochrony prawnej na rzecz członków tych organizacji. Warto jednak zauważyć, że przepisy prawa kształtujące status organizacji przedsiębiorców umożliwiają im bezpośrednie uczestnictwo w zamówieniach publicznych w charakterze wykonawców. Podstawę stanowi w tym zakresie osobowość prawna oraz wynikająca z niej możliwość prowadzenia działalności gospodarczej, jeśli jej przedmiot odpowiada wyznaczonemu ustawowo przedmiotowi zamówień publicznych.
\end{abstract}

Słowa kluczowe: organizacje przedsiębiorców, środki ochrony prawnej, zamówienia publiczne, wykonawcy, osobowość prawna, działalność gospodarcza.

\section{Wprowadzenie}

Bez wątpienia przedsiębiorcy jako podmioty działalności gospodarczej ${ }^{1}$ mogą uczestniczyć w zamówieniach publicznych w charakterze wykonawców, a zatem mogą być stroną umowy o zamówienie publiczne ze wszystkimi wynikającymi $z$ tego konsekwencjami. Inaczej jednak, bo w sposób niejednoznacznie i w pełni nieustalony, w zamówieniach publicznych uczestniczyć mogą także organizacje zrzeszające przedsiębiorców, a to z racji ich statusu prawnego, celów oraz zadań określonych prawnie.

Organizacje przedsiębiorców funkcjonujące w Polsce mają zróżnicowany charakter prawny. Pewna ich część należy do kategorii obligatoryjnych zrzeszeń pod-

${ }^{1}$ Na temat przedsiębiorcy zob. A. Powałowski, [w:] A. Dobaczewska, A. Powałowski, H. Wolska, Nowe prawo przedsiębiorców, Warszawa 2018, s. 1-25.

Prawo 329, 2020

(C) for this edition by CNS 
miotów zajmujących się podobną przedmiotowo działalnością gospodarczą. Są to przede wszystkim organizacje korporacyjne, grupujące osoby fizyczne wykonujące wolne zawody jako przedsiębiorcy. Wskazać należy także na organizacje, które będąc zrzeszeniami dobrowolnymi, skupiają przedsiębiorców według kryterium terytorialnego lub branżowego, jak również organizacje będące de nomine samorządem gospodarczym, gromadzące wybrane, wskazane przez ustawodawcę, grupy przedsiębiorców. Gdyby przyjąć, że podmioty wykonujące działalność rolniczą są także przedsiębiorcami, wówczas trzeba by nadto wskazać na organizacje samorządu rolniczego. Te ostatnie jednak nie są uwzględnione w przepisach Prawa zamówień publicznych.

Rola tych organizacji w obszarze zamówień publicznych zostanie scharakteryzowana w dalszej części opracowania. Wydaje się, że uzasadnione będzie wskazanie na zadania tych organizacji i formy ich udziału w zamówieniach publicznych, a następnie na cel tego udziału i ewentualne jego konsekwencje prawne.

Zasadne i celowe jest przyjęcie, że organizacje przedsiębiorców, podobnie jak sami przedsiębiorcy — członkowie tych organizacji, mogą występować w obrocie prawnym jako podmioty działalności gospodarczej, a więc jako przedsiębiorcy. Podstawą zarówno formalną, jak i materialną jest osobowość prawna tych organizacji, wynikająca z racji ich wpisywania do Krajowego Rejestru Sądowego $^{2}$ i potwierdzona dodatkowo przepisami szczególnymi, określającymi status prawny poszczególnych organizacji.

Ponadto należy zauważyć, że przyjmując możliwość (lecz nie obowiązek) leżącą po stronie wskazanych organizacji przedsiębiorców, a więc wykonywanie działalności gospodarczej, możliwe jest w konsekwencji występowanie tych organizacji w charakterze wykonawców zamówień publicznych. Zgodnie z treścią art. 2 pkt 11) ustawy Prawo zamówień publicznych ${ }^{3}$, wskazując na wykonawcę, należy uznawać za niego osobę fizyczną, osobę prawną albo jednostkę organizacyjną niemającą osobowości prawnej, która ubiega się o udzielenie zamówienia publicznego, złożyła ofertę lub zawarła umowę w sprawie zamówienia publicznego. Zamówienie publiczne to natomiast - stosownie do pkt 13 wskazanego artykułu ustawy p.z.p. - umowa odpłatna zawarta między zamawiającym a wykonawcą, której przedmiotem są usługi, dostawy lub roboty budowlane. W sytuacji gdy zamówienie realizowane jest zarobkowo, w sposób zorganizowany i ciągły oraz we własnym imieniu danego podmiotu, należy przyjąć, że stosownie do treści art. 3 ustawy Prawo przedsiębiorców ${ }^{4}$ dany podmiot wykonuje działalność gospodarczą.

2 Zob. ustawa z dnia 20 sierpnia 1997 roku o Krajowym Rejestrze Sądowym, tekst jedn. Dz.U. z 2019 r. poz. 1500.

3 Zob. ustawa z dnia 29 stycznia 2004 roku Prawo zamówień publicznych, tekst jedn. Dz.U. z 2019 r. poz.1843, dalej: ustawa p.z.p.

${ }^{4}$ Zob. ustawa z dnia 6 marca 2018 roku Prawo przedsiębiorców, tekst jedn. Dz.U. z 2019 r. poz. 1292 . 
W rozważaniach dotyczących udziału organizacji przedsiębiorców w zamówieniach publicznych trzeba również uwzględnić wszelkie przepisy dotyczące warunków, jakie powinien spełniać wykonawca biorący udział w postępowaniu w sprawie udzielenia zamówienia, oraz art. 4 ustawy p.z.p. określający wyłączenia przedmiotowe w stosowaniu przedmiotowej regulacji prawnej.

\section{Organizacje przedsiębiorców wykonujących wolne zawody i ich rola w zamówieniach publicznych}

Tworzenie organizacji przedsiębiorców wykonujących wolne zawody przewidziane jest w Konstytucji RP. Zgodnie z art. 17 można, w drodze ustawy, tworzyć samorządy zawodowe, reprezentujące osoby wykonujące zawody zaufania publicznego ${ }^{5}$. Samorządy te powinny sprawować pieczę nad należytym wykonywaniem tych zawodów w granicach interesu publicznego i dla jego ochrony. Również w drodze ustawy można tworzyć inne rodzaje samorządu, przy czym nie mogą one naruszać wolności wykonywania zawodu ani ograniczać wolności podejmowania działalności gospodarczej.

Najczęściej spotykane są, powoływane przez ustawy, samorządy wolnych zawodów. Wśród nich należy wskazać samorząd architektów i inżynierów budownictwa ${ }^{6}$ jako ten, który jako jedyny został wymieniony wśród innych samorządów zawodowych w treści art. 154a ustawy p.z.p. Przepis ten stanowi, że samorząd zawodowy architektów oraz inżynierów budownictwa może ubiegać się o wpis na listę organizacji uprawnionych do wnoszenia środków ochrony prawnej prowadzoną przez Prezesa Urzędu Zamówień Publicznych (UZP) ${ }^{7}$.

Wskazany samorząd zawodowy może w konsekwencji wnosić środki ochrony prawnej określone w dziale VI ustawy p.z.p., które zasadniczo przysługują — zgodnie z art. 179 ust. 1 tej ustawy - wykonawcy, uczestnikowi konkursu, a także innemu podmiotowi, jeżeli ma lub miał interes w uzyskaniu danego zamówienia oraz poniósł lub może ponieść szkodę w wyniku naruszeń przepisów przedmiotowej ustawy przez zamawiającego. Uprawnienie to przystaje, jak się wydaje, do zadań samorządu architektów i inżynierów budownictwa (należą do nich w szczególności: sprawowanie nadzoru nad należytym i sumiennym wykonywaniem zawodu przez członków samorządu; reprezentowanie i ochrona ich

5 Zob. P. Rączka, Działalność prawodawcza samorządów zawodowych w Polsce, Torun 2013.

6 Zob. ustawa z dnia 15 grudnia 2000 roku o samorządzie zawodowym architektów i inżynierów budownictwa, tekst jedn. Dz.U. z 2019 r. poz. 1117.

${ }^{7}$ Listę tę prowadzi i ogłasza Prezes UZP na stronie internetowej Urzędu Zamówień, www. uzp.gov.pl. 
interesów zawodowych; ustalanie zasad etyki zawodowej i nadzór nad jej przestrzeganiem; nadawanie i pozbawianie uprawnień budowlanych, uznawanie kwalifikacji zawodowych oraz nadawanie i pozbawianie tytułu rzeczoznawcy budowlanego; współdziałanie $\mathrm{z}$ organami administracji rządowej i organami samorządu terytorialnego oraz z innymi samorządami zawodowymi i stowarzyszeniami zawodowymi; prowadzenie postępowań w zakresie odpowiedzialności zawodowej i dyscyplinarnej członków samorządów zawodowych).

Każde z wyszczególnionych zadań samorządu może stać się przesłanką dla zgromadzenia przez ten samorząd odpowiednich, merytorycznych oraz formalnych argumentów pozwalających na właściwe, optymalne wsparcie środka ochrony prawnej. Wniesienie odwołania (art. 180 n. ustawy p.z.p.), a następnie skargi do sądu (art. 198a n. ustawy p.z.p.) wymaga przecież przeprowadzenia postępowania dowodowego (art. 190 ustawy p.z.p.), a więc — w tym zakresie — samorząd zawodowy może podjąć nieocenione działania.

W związku z tym zdaje się, że tożsame uprawnienie do wnoszenia środka ochrony prawnej powinno przysługiwać także innym samorządom zawodowym, które, reprezentując interesy swoich członków, miałyby w ramach tej reprezentacji możliwość wsparcia ich w toku postępowania odwoławczego i skargowego w zamówieniach publicznych. Jest przy tym oczywiste, że członkowie samorządów zawodowych mogą uczestniczyć w zamówieniach w charakterze wykonawców, jeśli występują (a w znaczącej część przypadków występują) oni w roli przedsiębiorców.

Warto także zauważyć, że samorządy zawodowe wyposażone są w osobowość prawną i niejako w konsekwencji posiadania między innymi tej cechy mają możliwość prowadzenia działalności gospodarczej ${ }^{8}$. Tym samym samorządy zawodowe mogą uczestniczyć w zamówieniach publicznych jako wykonawcy. Definicję wykonawcy zawiera art. 2 pkt 11 ustawy p.z.p. i stosownie do niej wyposażony w osobowość prawną samorząd zawodowy może stać się wykonawcą jako osoba prawna, która ubiega się o udzielenie zamówienia publicznego, złożyła ofertę lub zawarła umowę o zamówieniach publicznych. Nie ma żadnych przeszkód, by umowa taka obejmowała swoim przedmiotem usługi, dostawy lub roboty budowlane ${ }^{9}$. Jeżeli zamówienia wykonywane są w celu zarobkowym, w sposób zorganizowany i ciągły oraz we własnym imieniu wykonawcy, stanowią działalność gospodarczą w rozumieniu ustawy Prawo przedsiębiorców, a wykonawca (osoba prawna) działa jako przedsiębiorca.

${ }^{8}$ Zob. np. powołana wcześniej ustawa o samorządach zawodowym architektów i inżynierów budownictwa (art. 7).

9 Zakładając spełnienie innych warunków podmiotowych wskazanych w ustawie p.z.p. 


\section{Tak zwany samorząd zawodowy niektórych przedsiębiorców w zamówieniach publicznych}

„Samorząd zawodowy niektórych przedsiębiorców” stanowią organizacje podmiotów prowadzących działalność gospodarczą w zakresie handlu, gastronomii i usług, transportu, a także (bliżej nieokreślonych) innych rodzajów działalności ${ }^{10}$. $\mathrm{Z}$ tego zakresu wyłączone zostały jednak podmioty mające status rzemieślnika ${ }^{11}$.

Organizacje wskazanych przedsiębiorców mogą być tworzone dobrowolnie jako zrzeszenia handlu i usług oraz transportu, a także jako nienazwane przez ustawę, lecz określone mianem innych organizacji przedsiębiorców.

Wynika z tego jednoznacznie, że członkiem ,samorządu zawodowego niektórych przedsiębiorców" może być zasadniczo każdy przedsiębiorca (z uwzględnieniem ustawowego wyłączenia rzemieślników) i zarazem wszyscy przedsiębiorcy (również z wyłączeniem rzemieślników) mogą tworzyć w ramach tego samorządu organizacje o bliżej nieokreślonym statusie i charakterze. Wypada zauważyć, że nie było to zapewne zamiarem ustawodawcy, który uchwalił powołaną ustawę. Nieprawidłowe w konsekwencji jest jednak ustawowe złączenie organizacji przedsiębiorców omawianego „samorządu” wyłącznie z nazwą ,zrzeszenie” (art. 4-7 ustawy o samorządzie zawodowym niektórych przedsiębiorców).

Zadaniem zrzeszenia jest w szczególności utrwalanie więzi środowiskowych, postaw zgodnych z zasadami etyki i godności zawodu, a także prowadzenie na rzecz członków działalności kulturalnej, oświatowej i socjalnej, zakładanie i prowadzenie kas oraz funduszów zapomogowo-pożyczkowych oraz reprezentowanie interesów członków wobec organów administracji państwowej.

Organizacje przedsiębiorców, o których mowa we wskazywanej ustawie, podlegają obowiązkowi wpisu do Krajowego Rejestru Sądowego i uzyskują osobowość prawną z chwilą takiego wpisu. Osobowość prawna stwarza tym organizacjom możliwość prowadzenia działalności gospodarczej i występowania w roli przedsiębiorców. W efekcie organizacje te, prowadząc działalność gospodarczą będącą przedmiotem zamówień publicznych, mogą występować w charakterze wykonawców zamówień. Nie ma w tym względzie jakichkolwiek ograniczeń ustawowych, w tym zakazu wykonywania działalności gospodarczej.

Niezależnie od tego organizacje samorządu zawodowego niektórych przedsiębiorców są powołane do wnoszenia środków ochrony prawnej w trybie art. 154a ustawy p.z.p., zapewniając w ten sposób ochronę interesów członków danej organizacji, jak i ochronę rynku zamówień publicznych przed nieprawidło-

10 Zob. R. Kmieciak, Samorząd zawodowy, [w:] Encyklopedia politologii. Ustroje państwowe, t. 2, red. W. Skrzydło, M. Chmaj, Kraków 2000, s. 356-357; idem, Ustrój i zadania samorządu zawodowego, [w:] Samorząd w Polsce - istota, formy, zadania, red. S. Wykrętowicz, Poznań 2008.

11 Zob. ustawa z dnia 30 maja 1989 roku o samorządzie zawodowym niektórych przedsiębiorców, Dz.U. z 1989 r. Nr 35, poz.194 ze zm. 
wymi działaniami podmiotów zamawiających ${ }^{12}$. Podobnie zatem jak organizacje samorządu zawodowego mogą one ubiegać się o wpis na listę organizacji uprawnionych prowadzoną przez Prezesa UZP.

\section{Izby gospodarcze w sferze zamówień publicznych}

Powszechny zakres podmiotowy mają izby gospodarcze, do których należeć mogą — na zasadzie dobrowolności — wszyscy przedsiębiorcy ${ }^{13}$. Z przepisów ustawy o izbach gospodarczych ${ }^{14}$ nie wynikają w tej materii jakiekolwiek ograniczenia. Mogą to być zatem przedsiębiorcy należący do poszczególnych samorządów zawodowych, jak i przedsiębiorcy-rzemieślnicy oraz przedsiębiorcy mający możliwość tworzenia zrzeszeń i innych organizacji kwalifikowanych do tak zwanego samorządu zawodowego niektórych przedsiębiorców. Każda izba gospodarcza określana jest mianem organizacji samorządu gospodarczego, reprezentującej interesy gospodarcze zrzeszonych w niej przedsiębiorców, w szczególności wobec organów władzy publicznej. Celem funkcjonowania izb jest kształtowanie i upowszechnianie zasad etyki w działalności gospodarczej, w szczególności opracowywanie i doskonalenie norm rzetelnego postępowania w obrocie gospodarczym.

Do zadań izb, stosownie do przepisów ustawy o izbach gospodarczych (art. 4-5), należy w szczególności: wyrażanie opinii o projektach rozwiązań odnoszących się do funkcjonowania gospodarki oraz uczestniczenie w przygotowywaniu projektów aktów prawnych w tym zakresie; dokonywanie ocen wdrażania i funkcjonowania przepisów prawnych dotyczących prowadzenia działalności gospodarczej; przyczynianie się do tworzenia warunków rozwoju życia gospodarczego oraz wspieranie inicjatyw gospodarczych członków; delegowanie swoich przedstawicieli, na zaproszenie organów państwowych, do uczestniczenia w pracach instytucji doradczo-opiniodawczych w sprawach działalności wytwórczej, handlowej, budowlanej i usługowej; organizowanie i stwarzanie warunków do rozstrzygania sporów $\mathrm{w}$ drodze postępowania polubownego i pojednawczego oraz uczestniczenia w postępowaniu sądowym w związku z działalnością gospodarczą członków; wydawanie opinii o istniejących zwyczajach dotyczących działalności gospodarczej, a także informowanie o funkcjonowaniu przedsiębiorców oraz wyrażanie opinii o stanie rozwoju gospodarczego na obszarze działania

12 Zob. orzeczenie Krajowej Izby Odwoławczej z dnia 21 kwietnia 2017 roku (KIO 625/17, LEX nr 2319191), wyrok KIO z dnia 15 czerwca 2015 roku (KIO 1040/15, 1043/15, LEX nr 1800078).

13 Szerzej na temat form zrzeszania podmiotów prowadzących działalność gospodarczą zob. K. Kopaczyńska-Pieczniak, Korporacja. Elementy konstrukcji prawnej, Warszawa 2019.

14 Zob. ustawa z dnia 30 maja 1989 roku o izbach gospodarczych, tekst jedn. Dz.U. z 2019 r. poz. 579. 
danej izby. Zadania te mogą być realizowane przez izby, choć organizacje te nie mają obowiązku ich podejmowania (zob. art. 5 ust. 2).

Wskazane zadania, jak się wydaje, stanowią dobrą merytorycznie podstawę do skorzystania przez izby gospodarcze z możliwości umieszczenia na liście Prezesa UZP i w efekcie podjęcia przez konkretną izbę działań polegających na wniesieniu środka ochrony prawnej (odwołania i skargi do sądu) w przypadkach wskazanych w ustawie p.z.p.

Na wniosek lub za zgodą izby gospodarczej Rada Ministrów może, w drodze rozporządzenia, powierzyć określonej izbie wykonywanie niektórych zadań zastrzeżonych w przepisach prawa dla administracji państwowej (art. 5 ust. 3).

Podobnie jak inne organizacje przedsiębiorców również izby gospodarcze oraz ich jednostki organizacyjne podlegają obowiązkowi wpisu do Krajowego Rejestru Sądowego, w wyniku czego — z chwilą wpisu — uzyskują osobowość prawną. Istotne wydaje się ustalenie zawarte w ustawie o izbach gospodarczych, że każda izba gospodarcza może prowadzić działalność gospodarczą na zasadach ogólnych, a więc stosownie do przepisów ustawy Prawo przedsiębiorców (zob. art. 14 ust. 2). Dochód z działalności gospodarczej izby służy realizacji celów statutowych i nie może być przeznaczony do podziału między jej członków. Tym samym każda izba gospodarcza może — jako przedsiębiorca — uzyskać status prawny wykonawcy w sferze zamówień publicznych.

\section{Organizacje przedsiębiorców-rzemieślników i ich udział w zamówieniach publicznych}

Jak wskazuje się w ustawie o rzemiośle ${ }^{15}$, organizacjami przedsiębiorców-rzemieślników, czyli organizacjami samorządu gospodarczego rzemiosła, są: cechy, izby rzemieślnicze oraz Związek Rzemiosła Polskiego ${ }^{16}$. Organizacje rzemiosła tworzone są z inicjatywy członków na zasadzie dobrowolnej przynależności.

Ponieważ do rzemiosła nie zalicza się działalności handlowej, usług hotelarskich, działalności transportowej, usług świadczonych w wykonywaniu wolnych zawodów, usług leczniczych oraz działalności wytwórczej i usługowej artystów, plastyków i fotografików, w konsekwencji organizacje rzemieślników nie obejmują swoim zakresem podmiotowym przedsiębiorców wykonujących wskazaną działalność gospodarczą.

15 Zob. ustawa z dnia 22 marca 1989 roku o rzemiośle, tekst jedn. Dz.U. z 2018 r. poz. 1267.

16 Więcej zob. K. Bandarzewski, Samorząd gospodarczy w prawie polskim. Studium prawne, Kraków 2014; A Szustek, Samorzą - samorząd gospodarczy - inne rodzaje samorząu. Siatka pojęciowa, ujęcie teoretyczne i zagadnienia metodologiczne, Warszawa 2017. 
Do zadań samorządu gospodarczego rzemiosła należy w szczególności: promocja działalności gospodarczej i społeczno-zawodowej rzemiosła; nadzór nad organizacją i przebiegiem procesu przygotowania zawodowego w rzemiośle; udzielanie pomocy rzemieślnikom i innym przedsiębiorcom zrzeszonym $\mathrm{w}$ organizacjach samorządu gospodarczego rzemiosła oraz reprezentowanie interesów środowiska rzemieślniczego wobec organów administracji publicznej.

Jednym z podstawowych zadań organizacji samorządu rzemiosła według ustawy o rzemiośle (art. 12 ust. 4) jest prezentowanie interesów członków tych organizacji wobec organów administracji i sądów, a w wypadku Związku Rzemiosła Polskiego także reprezentowanie interesów rzemiosła, jako określonej grupy zawodowej, w kraju i za granicą.

Zapewne i w przypadku organizacji rzemieślniczych wyznaczone przez ustawę o rzemiośle zadania są przesłanką stwarzającą możliwość występowania tych organizacji w zamówieniach publicznych i składanie, w imieniu członków organizacji samorządu rzemieślniczego, środków ochrony prawnej w trybie art. 154a ustawy p.z.p.

Organizacje samorządu gospodarczego rzemiosła podlegają obowiązkowi wpisu do Krajowego Rejestru Sądowego i uzyskują osobowość prawną z chwilą wpisania do tego rejestru. Analogicznie jak w wypadku innych organizacji przedsiębiorców osobowość prawna daje odpowiednią podstawę prawną i stwarza możliwość prowadzenia przez organizacje rzemiosła działalności gospodarczej, jak się wydaje, w pełnym zakresie przedmiotowym (a więc bez ograniczeń, o których mowa w art. 2 ust. 4 ustawy o rzemiośle), przy czym ustawa ta nie wskazuje expressis verbis na taką możliwość.

Prowadzenie działalności gospodarczej przez organizacje samorządu rzemieślniczego pozwala tym organizacjom uczestniczyć w zamówieniach publicznych w roli wykonawców określonego zamówienia.

\section{Udział organizacji pracodawców w zamówieniach publicznych}

Stosownie do treści art. 154a w zw. z art. 154 pkt 5 ustawy p.z.p. na listę organizacji uprawnionych do wnoszenia środków ochrony prawnej (prowadzonej przez Prezesa UZP) mogą, oprócz wskazanych już organizacji przedsiębiorców, zostać wpisane także organizacje pracodawców ${ }^{17}$. Organizacje te mogą tworzyć pracodawcy, czyli podmioty, o których mowa w ustawie o związkach

17 Zob. art. 1 ust. 1 ustawy z dnia 23 maja 1991 roku o organizacjach pracodawców, tekst jedn. Dz.U. z 2019 r. poz. 1809. 
zawodowych ${ }^{18}$. Sa to podmioty - osoby fizyczne, osoby prawne lub jednostki organizacyjne niemające osobowości prawnej — zatrudniające pracowników lub osoby niemające statusu pracowników, niezależnie od podstawy zatrudnienia. Podmioty te wyróżnia zatem — spośród innych — zatrudnianie osób wykonujących na ich rzecz pracę ${ }^{19}$.

Organizacje pracodawców (według ustawy o organizacjach pracodawców: związki pracodawców) mają prawo tworzenia federacji i konfederacji, jak też przystępowania do nich, a każdy związek, federacja i konfederacja ma prawo do przystępowania do międzynarodowych organizacji pracodawców. Wszystkie te organizacje są samorządne i niezależne w swej działalności statutowej od organów administracji rządowej, samorządu terytorialnego oraz innych organizacji.

Podstawowym zadaniem związków pracodawców, ich federacji i konfederacji jest ochrona praw i reprezentowanie interesów, w tym gospodarczych, zrzeszonych członków wobec związków zawodowych, organów władzy i administracji rządowej oraz organów samorządu terytorialnego. Związki pracodawców uczestniczą w prowadzeniu rokowań zbiorowych, w zawieraniu układów zbiorowych pracy oraz innych porozumień w zakresie objętym ich zadaniami statutowymi.

Związek pracodawców podlega obowiązkowi rejestracji w Krajowym Rejestrze Sądowym. Nabywa on osobowość prawną z dniem zarejestrowania go w KRS. Osobowość prawna wskazanych organizacji jest przesłanką do wykonywania przez te organizacje działalności gospodarczej, o której to możliwości ustawa o organizacjach pracodawców wspomina jedynie w aspekcie osiągania dochodu. Dochód z działalności gospodarczej prowadzonej przez związki pracodawców oraz federacje i konfederacje służy mianowicie realizacji ich zadań statutowych i nie może być przeznaczony do podziału między ich członków ${ }^{20}$. Organizacje te korzystają ze zwolnień podatkowych przewidzianych dla stowarzyszeń.

Wobec tego organizacje pracodawców wykonujące działalność gospodarczą mogą być, na gruncie przepisów ustawy Prawo przedsiębiorców, potraktowane jako przedsiębiorcy. Jeżeli ich działalność gospodarcza mieści się w ramach przedmiotowych zamówień publicznych, to tym samym mogą być one potraktowane jako wykonawcy zamówień. Ustalenie to w żaden sposób nie zmienia statusu prawnego tych organizacji jako związków, których członkami są zarówno pracodawcy wykonujący działalność gospodarczą, jak i pracodawcy niewykonujący takiej działalności.

18 Zob. art. pkt 2 ustawy z dnia 23 maja 1991 roku o związkach zawodowych, tekst jedn. Dz.U. z 2019 r. poz. 263.

19 J. Piątkowski, Komentarz do art. 1 ustawy o organizacjach pracodawców, [w:] Zbiorowe prawo zatrudnienia. Komentarz, red. K.W. Baran, Warszawa 2019, LEX, stan prawny na: 1.04.2019.

20 J. Piątkowski, Komentarz do art. 18 ustawy o organizacjach pracodawców, LEX, stan prawny na: 1.04.2019. 
Należy zarazem jednak przyjąć, że niepodejmowanie przez organizacje pracodawców działalności gospodarczej wyklucza je z grona przedsiębiorców oraz w konsekwencji także wykonawców zamówień publicznych.

\section{Uwagi końcowe}

Wolność zrzeszania się w związkach i organizacjach społecznych, zawodowych oraz gospodarczych wynikająca z art. 12 i 59 Konstytucji RP w pełnej rozciągłości dotyczy podmiotów działalności gospodarczej - przedsiębiorców. Przedsiębiorcy, realizując swoje prawo do zrzeszania się, powinni jednak mieć na względzie nie tylko to prawo, lecz także swoje korzyści wynikające z przynależności do różnego rodzaju związków i organizacji. W większości przypadków, z wyjątkiem samorządu zawodowego wolnych zawodów oraz samorządu rolniczego, organizacje skupiające przedsiębiorców mają charakter dobrowolny. Ma to niewątpliwy wpływ na kwestię reprezentatywności tych organizacji. Wydaje się również ważne, by przedsiębiorcy mieli wiedzę odnośnie do zakresu i charakteru zadań, jakie określona organizacja może podejmować.

Dla przedsiębiorcy powinno być także istotne, jaką zdolność „organizacyjną" ma dana organizacja przedsiębiorców, a więc, czy jest ona sprawna w toku podejmowanych przez siebie zadań, głównie w sferze reprezentowania interesów podmiotów zrzeszonych, a ponadto, jakimi środkami działania może wykonywać swoje kompetencje określone w normach prawa.

Organizacje przedsiębiorców nie są objęte zakazami uczestnictwa w zamówieniach publicznych w charakterze wykonawców, choć zarazem ich zadania nie wskazują w sposób wyraźny na możliwość takiego uczestnictwa.

Jak można wywnioskować z wcześniej omówionych ustaw określających status prawny poszczególnych organizacji skupiających przedsiębiorców, nie wynika wprost, że dana organizacja — dobrowolna lub obligatoryjna - ma możliwość występowania w roli wykonawcy zamówień publicznych. Spełniają one jednak wymogi formalne do pełnienia takiej roli na gruncie przepisów ustawy Prawo zamówień publicznych, co starano się wykazać w niniejszym tekście.

Zasadniczo wątpliwości nie budzi udział omawianych organizacji w procedurze wnoszenia środków ochrony prawnej wykonawców, a zarazem przedsiębiorców zrzeszonych w tych organizacjach. Co najwyżej, jak wcześniej zaznaczono, można sądzić, iż trudna jest pełna identyfikacja składu podmiotowego tych organizacji, a tym samym ich reprezentatywność. Ta kwestia zdaje się właściwa do scharakteryzowania w innej publikacji.

Trzeba zarazem stwierdzić, że analogiczne rozwiązania dotyczące udziału organizacji przedsiębiorców, w tym organizacji pracodawców, jak te tutaj scharakteryzowane, wynikające $\mathrm{z}$ aktualnie obowiązującej ustawy Prawo zamówień 
publicznych, zawiera także nowo uchwalona ustawa z dnia 11 września 2019 roku Prawo zamówień publicznych ${ }^{21}$.

\section{Bibliografia}

Bandarzewski K., Samorzą gospodarczy w prawie polskim. Studium prawne, Kraków 2014.

Kmieciak R., Samorzad zawodowy, [w:] Encyklopedia politologii. Ustroje państwowe, t. 2, red. W. Skrzydło, M. Chmaj, Kraków 2000.

Kmieciak R., Ustrój i zadania samorządu zawodowego, [w:] Samorząd w Polsce - istota, formy, zadania, red. S. Wykrętowicz, Poznań 2008.

Kopaczyńska-Pieczniak K., Korporacja. Elementy konstrukcji prawnej, Warszawa 2019.

Piątkowski J., Komentarz do art. 1 ustawy o organizacjach pracodawców, [w:] Zbiorowe prawo zatrudnienia. Komentarz, red. K.W. Baran, Warszawa 2019, LEX, stan prawny na: 1.04.2019.

Piątkowski J., Komentarz do art. 18 ustawy o organizacjach pracodawców, LEX, stan prawny na: 1.04.2019.

Powałowski A., [w:] A. Dobaczewska, A. Powałowski, H. Wolska, Nowe prawo przedsiębiorców, Warszawa 2018.

Rączka P., Działalność prawodawcza samorządów zawodowych w Polsce, Torun 2013.

Szustek A., Samorzą - samorząd gospodarczy — inne rodzaje samorządu. Siatka pojęciowa, ujęcie teoretyczne i zagadnienia metodologiczne, Warszawa 2017.

\section{The role of business organisations in the sphere of public procurement}

\section{Summary}

Organisations of entrepreneurs may also participate in public procurement. Such organisations operating in Poland have a diverse legal character. These are in particular professional self-government organisations, chambers of commerce and other associations. According to the Public Procurement Law, they are entitled to bring legal protection measures for the members of these organisations. It is worth noting, however, that provisions of law shaping the status of business organisations allow them to participate directly in public procurement as contractors. The basis for this is their legal personality and hence the opportunity to conduct business, if its subject corresponds to the statutory subject of public procurement.

Keywords: business organizations, legal protection measures, public procurement, contractors, legal personality, business activity.

21 Dz.U. z 2019 r. poz. 2019. 